\title{
The Effect of Health Education on Knowledge and Attitude in First Aid Food Poisoning in Students of SD N 1 Kutasari
}

\author{
Eva Fatmawati ${ }^{1}$, Nurul Fatwati Fitriana ${ }^{2}$ \\ ${ }^{1,2}$ Department of Health, Universitas Muhammadiyah Purwokerto, Indonesia
}

\begin{tabular}{|c|c|}
\hline ARTICLE INFO & ABSTRACT \\
\hline Article history: & $\begin{array}{l}\text { Poisoning is an emergency caused by the entry of a harmful substance or } \\
\text { food into the body in various ways. This research aimed to figure out the }\end{array}$ \\
\hline $\begin{array}{l}\text { DOI: } \\
10.30595 / \text { pshms.v2i.237 } \\
\end{array}$ & $\begin{array}{l}\text { effect of health education about the first aid for food poisoning on the } \\
\text { knowledge and attitude of students at SD } \mathrm{N} 1 \text { Kutasari. This was pre- } \\
\text { experimental quantitative research using a one group pretest-posttest }\end{array}$ \\
\hline $\begin{array}{l}\text { Submitted: } \\
\text { December 6, } 2021\end{array}$ & $\begin{array}{l}\text { research design. Based on the Wilcoxon test results, the significance value } \\
\text { was } 0.001 \text { (p0.05), while based on the Paired T-test results was } 0.000 \\
\text { (p0.05). There is an effect of health education on the knowledge and attitude } \\
\text { of students for the first aid for food poisoning at SD N } 1 \text { Kutasari }\end{array}$ \\
\hline
\end{tabular}

Accepted:

January 21, 2022

Published:

January 26, 2022

Keywords:

Food poisoning, First aid

This work is licensed under a Creative Commons Attribution 4.0

International License.



\section{Corresponding Author:}

Nurul Fatwati Fitriana,

Department of Health, Universitas Muhammadiyah Purwokerto,

Soepardjo Rustam Street KM. 7, Banyumas, Indonesia

Email: nurulfatwati90@gmail.com

\section{INTRODUCTION}

Food poisoning is a disease caused by poison or Bacteria that are in the food and now have become a problem for community. Over the centuries, the type, severity, and impact Foodborne illness has changed, but there are still differences between region, country, and community.[1]

Food poisoning occurs quite often in Indonesia. At In 2014, the total news of poisoning incidents reported from the mass media to the National Poisoning Information Center of the Food and Drug Administration $\mathrm{Ri}$ is as many as 186 (one hundred and eighty-six) poisoning incidents.Occurs in some parts of Indonesia.

Central Java Province became the highest klb contributing province in Indonesian. While in 2013 KLB food poisoning in Central Java While in 2013 KLB food poisoning in Java as many as 17 incidents 2 with 4,935 people exposed, while the sick as many as 952 people and 1 person with an attack rate (AR $19.30 \%$ ) and case fatality rate (CFR) $0.1 \%$. [2]

Poisoning is an important public health issue. It is an important part of the emergency services application. Needed A serious approach with the correct answer to the application First aid is done correctly and on time. Now Successful treatment can be improved by raising awareness.and protective measures 
related to this issue. In the case of poisoning, Proper first aid is saving lives, and this is applications that must be provided by all individuals regardless of medical studies. [3]

Poisoning is a condition that can be life-threatening. Get it right. Therefore, everyone should be able to First aid (Thygerson, 2011). But before in general emergencies People often panic, chaos and Hysterical ignorance, ignorance of what to do to solve that problem. This doubt arises between the two. because of ignorance and fear of the consequences of its causes. [4]

\section{RESEARCH METHOD}

This research uses quantitative methods, with an approach Pre-Experimental with One Group Pre and Post-test Design Design, namely Research consisting of one group.[5] Measurement This is done before and after intervention. This research aims to Know the effect of interventions carried out, namely health education knowledge and attitudes about first aid in poisoning food.

This research was conducted at SD N 1 Kutasari, Baturraden in April 2021. The number of respondents who participated in this study was 79 respondents, namely all elementary students N 1 Kutasari, Baturraden Banyumas Regency.

\section{RESULT AND DISCUSSIONS}

3.1 Univariate Analysis Results

Knowledge scores before and after being given Health Education about food poisoning first aid

\begin{tabular}{lcc}
\hline Parameter & Pre test & Post tset \\
\hline Mean & 8.78 & 13.47 \\
Median & 9.00 & 14.00 \\
Minimum & 5 & 12 \\
Maximum & 14 & 14 \\
\hline
\end{tabular}

The table above illustrates that knowledge of food poisoning first aid prior to the intervention in the form of Health Education has a minimum score of 5 maximum values of 14, a median of 9.00 and an average of 8.78. After the intervention, the minimum value increased to 12 , the maximum value was 14 , the median was 14 and the average increased to 13.47 .

\section{Attitude scores before and after being given Health Education about food poisoning first aid}

\begin{tabular}{|c|c|c|}
\hline Parameter & Pre test & Post tset \\
\hline Mean & 82.05 & 90.78 \\
\hline Median & 82.00 & 91.00 \\
\hline Minimum & 72 & 85 \\
\hline Maximum & 88 & 96 \\
\hline
\end{tabular}

Based on the table above, it can be seen that the attitudes of elementary school students before given health education, has a minimum score of 72 , a maximum score of 88 , has a median of 82.00 and a mean score of 82.05. After being given health education, the minimum score was 85 , the maximum score was 96 , the median was 91.00 and the average score was 90.78 . 


\subsection{Bivariate Analysis Results Normality}

\begin{tabular}{lcc}
\hline \multicolumn{1}{c}{ Variabel } & p value & Keterangan \\
\hline Pre Test Knowledge & .000 & Abnormal \\
Post Test Knowledge & .000 & Abnormal \\
Pre Test Attitude & .096 & Normal \\
Post Test Attitude & .099 & Normal \\
\hline
\end{tabular}

Normality test results can be seen in table 4.4 with the number of students as many as 79 children using the test to produce sig scores each on the pre test knowledge 0.00 , post test knowledge 0.00 , pre test attitude 0.96 and post test attitude 0.99 . Sig value on pre test and post test knowledge $<0.05$ so that the data is not distributed normally then the test used is the Wilcoxon test, while in the pre test and post test attitude > 0.05 , it can be called normal distributed data so that the test used is a paired t-test test.

Wilcoxon Test of Knowledge before and after health education

\begin{tabular}{lcc}
\hline Knowledge & Mean (Min-Maks) & -value \\
\hline Pre & $8,78(5-14)$ & 0,001 \\
Post & $9,00(12-14)$ & \\
\hline
\end{tabular}

The results of the Wilcoxon Signed Rank Test were obtained p-value $0.001(<0.05)$, meaning that there was an influence on health education on respondents' knowledge of food poisoning first aid.

Paired T-test Attitudes before and after health education

\begin{tabular}{ccc}
\hline Attitude & Mean (Min-Maks) & p-value \\
\hline Pre & $82,05(72-88)$ & 0,000 \\
Post & $90,78(85-94)$ & \\
\hline
\end{tabular}

Describing the results of the Paired T-test for the attitude of students before being given Health Education obtained an average score of 82.05 and after being given Health Education the average knowledge of 90.78.t score $\mathrm{t}$ calculated $-21,328$ and $\mathrm{p}$ value of 0.000 . Paired T-test results obtained $\mathrm{p}$-value $0.000(<$ 0.05), meaning there is an influence of Health Education about food poisoning first aid on the knowledge and attitude of elementary school students N 1 Kutasari, Baturraden.

\subsection{The Effect of Health Education on Knowledge and Food Poisoning First Aid Attitude}

The results of the study illustrate that before it was given health education, has a minimum value of 5, maximum grade 14, the standard deviation value is 2.011 , has a median of 9 and an average value of 8.78. After health education is given, the minimum value 12, maximum value 14, standard deviation value 6.57, median 14 and a grade point average of 13.47. Looking at this data, you can 66 It is said that health education affects Someone's knowledge. All 79 respondents (100\%), have never previously received counseling or Education on food poisoning first aid.Average before education Health 8.78 increased to 13.47.

Knowledge has a definition that is the result of know and happen after the person who did the sensing

to a particular object where most Human knowledge is gained through the eyes and ears. [6]

[7] he stated that knowledge can be changed by persuasion strategies, namely by providing information to others through health education carried out by various methods, one of which is by providing leaflet media and materials in the form of lectures. The process of giving material with lecture methods and the existence of two-way communication, namely between the health education provider and the question from the respondent will make the knowledge provided easy to digest so that the respondent will be easier to understand the material that has been delivered. 
According to [8], Knowledge of first aid is important in the safety of victims, it is better to know about first aid and not need it than to need first aid but not know about first aid. Everyone should know about first aid.

Health Education is carried out by lecture method and uses two-way communication, namely health education givers and questions from respondents will make the knowledge provided easily digested by students. Giving with a lecture method interspersed with children's language will make children more concerned about the material that has been given. Material provided using stories, and about examples of unhealthy behaviors, such as rare hand washing, rare exercise. Respondents will be easier to understand the message in the message that is being delivered by the speaker. [9]

States that the goal of providing health education is to achieve changes in the behavior of individuals, families, and communities in fostering and maintaining healthy living behaviors and healthy environments, and playing an active role in efforts to realize optimal levels of health. [10]

\subsection{Results of Student Attitude Before and After Education Health on Food Poisoning First Aid}

Based on the results of the research that has been done, the result that the attitude of students before being given Health Education has a minimum value of 72, a maximum value of 88 , a median of 82 and a value Average of 82.05. After being given health education on first aid food poisoning, there is an increase significantly, the minimum value increases to 85 , the value maximum 96 , median 91.00 and average increases to 90.78. So it can be concluded that the attitude of students after being given Health education about food poisoning Influence on students.

According to [11] Attitude is a person's response. an object that has not been shown into behavior. Attitude This is the emotional response of a person to external object stimulus. This emotional response has a judgmental nature. or a personal evaluation of stimuli and can be continued with Do or not do to objects.

Based on some of the results of the above research, it can be concluded that health education in the form of counseling can be said effective to improve attitudes about first aid food poisoning due to almost all after-value studies health education is provided both in terms of knowledge and Attitude is always better than grades before being given education health.

\section{CONCLUSIONS}

Based on the results of research and discussion on "The Effect of Health Education on The Knowledge and Attitudes of Food Poisoning First Aid" produces conclusions and suggestions as follows: Respondents in the study were between the ages of 9-11 years old with the majority of respondents being from grade 5 as many as 46 respondents $(58.2 \%)$ and all (100\%) had never received health education on food poisoning first aid.

Before doing Health Education about knowledge has an average score of 8.78. After Health Education on knowledge, there was an increase in the average score to 13.47, Before doing Health Education about attitudes has an average score of 82.05, After Health Education on attitudes, there was an increase in the average score to 90.78 .

\section{Acknowledgements}

Thank you to Allah SWT, both parents and all comrades in arms who have helped from beginning to end.

\section{REFERENCES}

[1] WHO, "Who Estimates of The Global Burden of Foodborne Diseases," 2015

[2] BPOM RI, “Laporan Tahunan 2013 Badan Pengawas Obat dan Makanan RI,” Jakarta, 2013.

[3] Goktas, S., YILDIRIM, G., Selmin, K. O. S. E., YILDIRIM, S., OZHAN, F., \& SENTURAN, L., "First aid knowledge of university students in poisoning cases," Turkish journal of emergency medicine, 14(4), 153-159, 2014.

[4] Isti Mulyawati, Asih Kuswardinah, Ari Yuniastuti, "Pengaruh Pendidikan Kesehatan tentang Keamanan Jajanan terhadap Pengetahuan dan Sikap Anak," 2014.

[5] Setiyabudi, Ragil, "Diktat Ajar Ilmu Dasar Keperawatan 7," Universitas Muhammadiyah Purwokerto. (Tidak dipublikasikan), 2017.

[6] Notoadmodjo, S, “Metodologi Penelitian Kesehatan,’Jakarta: Rineka Cipta, 2017.

[7] Wawan A, Dewi M., “Teori dan Pengukuran Pengetahuan, Sikap dan Perilaku Manusia,” Yogyakarta: Nuha Medika, 2010.

[8] Thygerson, A, “Pertolongan Pertama,” Jakarta: Erlangga, 2011. 
[9] Pratama, R. K. O., "Pengaruh Pendidikan Kesehatan Terhadap Perubahan, Sikap dan Perilaku Tentang Kebiasaan Berperilaku Hidup Bersih dan Sehat Siswa SDN 1 Mandong (Doctoral dissertation)," Universitas Muhammadiyah Surakarta, 2013.

[10] Effendy, Nasrul, "Dasar - Dasar Keperawatan Kesehatan Masyarakat (Ed. 2),” Jakarta: EGC, 2012.

[11] Rahayu, C., Widiati, S., Widyanti, N., "Hubungan antara Pengetahuan, Sikap, dan Perilaku terhadap Pemeliharaan Kebersihan Gigi dan Mulut dengan Status Kesehatan Periodontal Pra Lansia di Posbindu Kecamatan Indihiang Kota Tasikmalaya”, Majalah Kedokteran Gigi. 21(1): 27-32, 2014. 